Fiat Justisia Jurnal Ilmu Hukum Volume 7 No. 2, Mei-Agustus 2013, $\quad$ ISSN 1978-5186

\title{
PENGELOLAAN ASET DAERAH MELALUI KEPEMILIKAN MODAL PADA BANK PEMBIAYAAN RAKYAT SYARIAH (BPRS) (Suatu Kajian Hukum Ekonomi)
}

\author{
Rilda Murniati \\ Dosen Bagian Hukum Keperdataan Fak. Hukum Unila \\ Email : rilda_murniati@fh.unil.ac.id
}

\begin{abstract}
Abstrak
Keikutsertaan Pemerintah Daerah dengan pembelian atau pengambilalihan saham Bank Pembiayaan Rakyat Syariah (BPRS) yang telah berdiri merupakan alternatif tercepat daripada mendirikan bank baru. Pendirian BPRS baru membutuhkan berbagai kajian mendalam, pemenuhan syarat yang cukup banyak, harus didukung berbagai dokumen dan prosedur pendirian sebagaimana diatur Undang-undang Perseroan Terbatas dan Perbankan Syariah. Berdasarkan kajian hukum ekonomi, pembelian atau pengambilalihan saham dilakukan dengan syarat dan prosedur relatif sederhana dan singkat. Pemerintah daerah dapat melakukan pembelian atau pengambilalihan modal atau saham BPRS tersebut berdasarkan kajian mendalam dan dengan alasan yang menguntungkan dalam peningkatan peran pemerintah daerah bagi kehidupan ekonomi masyarakat daerahnya dan peningkatan pengelolaan aset agar berhasil guna dan meningkatkan keuntungan bagi keuangan daerah.
\end{abstract}

Kata kunci : Modal, dan BPR Syariah

\section{Pendahuluan}

Bank syariah berkembang cukup pesat di dunia internasional dan di negara Indonesia. Perkembangan ini terjadi karena adanya dukungan dari berbagai aspek antara lain aspek sosial budaya masyarakat dan aspek kepastian hukum. Sejak tahun 1970-an, di dunia internasional perkembangan perbankan syariah telah merambah dan diterima bukan saja di negaranegara muslim tetapi juga negaranegara nonmuslim. Perbankan syariah terus tumbuh karena nilainilainya yang berorientasi pada etika bisnis sehat (Sutan Remy Sjadeini, 2002: 9).
Perbankan syariah di Indonesia berkembang pesat karena secara asas-asas atau prinsip perbankan syariah sesuai dengan budaya masyarakat yang sangat dipengaruhi oleh unsur agama tidak menghendaki adanya keuntungan yang diperolehnya dari uang yang ditanamkan pada lembang perbankan. Sebelum lahirnya Bank Muamalat yang merupakan bank umum syariah pertama di Indonesia 1991, BPR syariah telah lebih dahulu berdiri di Bandung dan Aceh 1990.

Kepastian hukum melalui UU Perbankan Syariah adalah salah satu aspek yang sangat menentukan bagi tumbuh dan terus berkembangnya bank syariah di Indonesia. Lahirnya UU No. 21 Tahun 2008 tentang 
Perbankan Syariah (selanjutnya disingkat UUPS) merupakan landasaan kepastian hukum yang kuat bagi para pelaku bisnis dan masyarakat luas untuk berinvestasi pada bank syariah (Gemala Dewi, 2005: 62). Berdasarkan UU Perbankan Syariah terdapat dua jenis bank syariah yaitu Bank Umum Syariah (BUS) dan Bank Pembiayaan Rakyat Syariah. UU Perbankan Syariah menegaskan kembali keberadaan bank umum konvensional dapat menjalankan usaha syariah dengan pembentukan Unit Usaha Syariah (UUS) sebagaimana telah diatur dalam UU Perbankan dan peraturan Bank Indonesia.

Di lihat dari kegiatan usahanya terdapat perbedaan prinsip antara kegiatan Bank Umum Syariah (BUS) dan Bank Pembiayaan Rakyat Syariah (BPRS). Hal ini sejalan dengan kegiatan usaha bank umum dan BPR sebagaimana diatur dalam UU Perbankan. Untuk itu, perbedaan prinsipnya adalah Bank Umum Syariah menjalankan kegiatan usaha dalam lalu lintas pembayaran sebagaimana ditentukan dalam Pasal 19 dan Pasal 20 UU Perbankan Syariah dan Peraturan Bank Indonesia sepanjang tidak bertentangan dengan UU Perbankan Syariah. Sedangkan BPRS menjalankan kegiatan usaha dengan tidak memberikan jasa dalam lalu lintas pembayaran dan sebagaimana ditentukan dalam Pasal 21 UU Perbankan Syariah dan Peraturan Bank Indonesia sepanjang tidak bertentangan dengan UU Perbankan Syariah.

Secara umum, penjelasan UU Perbankan menentukan bahwa kegiatan usaha bank umum berupa kegiatan yang memberikan jasa dalam lalu lintas pembayaran adalah kegiatan usaha di bidang jasa keuangan yang bersifat umum meliputi seluruh jasa perbankan sebagai lembaga keuangan yang terdiri atas menghimpun dana dari masyarakat dalam bentuk simpanan dan menyalurkan dana dalam bentuk kredit, dan bentuk-bentuk kegiatan lainnya. Sedangkan pengertian tidak memberikan jasa dalam lalu lintas pembayaran meliputi tidak menerima simpanan berupa giro yang tunduk pada lalu lintas pembayaran baik secara tunai maupun surat berharga atau pemindahbukuan. Pembatasan tersebut dimaksudkan untuk menyesuaikan dengan fungsi BPR yang ditujukan hanya untuk melayani usaha-usaha kecil dan masyarakat di pedesaan.

Berdasarkan jenis dan kegiatan usaha bank syariah maka antara BUS dan BPRS memiliki fungsi dan peran yang berbeda dalam hubungananya dengan masyarakat luas. BUS lebih menjalankan usaha perbankan pada umumnya dan masyarakat pada umumnya sedangkan fungsi BPRS lebih mengutamakan fungsinya secara khusus yaitu melayani masyarakat dengan investasi kecil termasuk masyarakat pedesaan dengan prinsip syariah. Berdasarkan fungsinya tersebut maka BPRS akan memiliki akses besar bagi pengembangan usaha kecil dan masyarakat kecil di Indoensia yang jumlah cukup besar dibandingkan dengan usaha menengah dan besar.

Pemerintah daerah di Indonesia dapat merencanakan untuk menginvestasikan dananya pada BPRS merupakan langkah strategis demi meletakkan salah satu peran 
Pemerintah Daerah secara langsung bagi kelangsungan ekonomi masyarakat dan meningkatkan pertumbuhan ekonomi dan pengelolaan pendapatan daerah. Untuk itu, sesuai dengan fungsi BPRS yang ditentukan dalam UU Perbankan dan UU Perbankan Syariah maka keikutsertaan Pemerintah Daerah untuk menginvestasikan dana dan aset daerah untuk pendirian BPRS baru dirasakan sangat diperlukan.

Pendirian BPRS baru membutuhkan berbagai pertimbangan hukum, sosial ekonomi dan politik dengan kajian yang mendalam dari Pemerintah Daerah dan DPRD. Dari segi sosial ekonomi, berdasarkan berbagai hasil penelitian (studi pustaka) memperlihatkan gambaran dukungan yang cukup potensial baik di dunia internasional maupun di negara kita Indonesia terhadap tumbuh dan berkembangnya perbankan syariah. Namun demikian, di lihat dari segi aspek hukum ekonomi, pendirian BPRS baru membutuhkan modal, adminstratif dan legalitas hukum yang cukup banyak dan waktu yang cukup lama dibandingkan dengan investasi melalui penyertaan modal pada BPRS yang telah berdiri.

Di lihat dari aspek hukum ekonomi, pendirian BPRS membutuhkan kesiapan syarat dan mengikuti prosedur pendirian yang telah ditentukan dalam UU Perbankan Syariah dan UU Perseroan Terbatas serta peraturan lain yang terkait dengan legalitas pendirian perusahaan baru termasuk BPRS baru. UU Perbankan Syariah, menentukan bahwa bentuk hukum bank syariah adalah Perseroan Terbatas.
Untuk itu, terdapat pengaturan yang berbeda dengan UU Perbankan dan Peraturan BI tentang bentuk hukum bank syariah yaitu Perseroan Terbatas, Koperasi dan Perusahaan Daerah. UU Perbankan Syariah tidak memungkinkan ada bentuk hukum lain di luar Perseroan Terbatas. Dengan demikian, sepanjang tidak ditentukan secara khusus dalam UU Perbankan Syariah maka peraturan perundang-undangan yang mengatur secara umum tentang pendirian dan legalitas hukum perbankan syariah berlaku terhadap bank syariah termasuk BPRS.

Berdasarkan uraian di atas, maka menjadi suatu kajian yang cukup menarik dari segi hukum ekonomi tentang pendirian bank syariah khususnya BPRS yang dapat dijadikan peluang investasi bagi pemerintah daerah dalam pengembangan modal daerah yang keuntungannya dapat digunakan bagi kegiatan pembangunan ekonomi daerah tersebut.

\section{Pembahasan}

\subsection{Syarat Pendirian BPRS}

Berdasarkan bentuk hukum, maka BPRS adalah Perseroan Terbatas. Pasal 1 ayat (1) UU Perseroan Terbatas (UUPT) menentukan bahwa Perseroan Terbatas adalah badan hukum yang merupakan persekutuan modal, didirikan berdasarkan perjanjian, melakukan kegiatan usaha dengan modal dasar yang seluruhnya terbagai dalam saham dan memenuhi persyaratan yang ditetapkan dalam UU ini serta peraturan pelaksanaanya. Untuk itu, maka terhadap syarat pendirian BPRS baru berlaku ketentuan UU Perbankan 
Syariah (UUPS) dan UU Perseroan Terbatas (UUPT).

\section{a. Kepemilikan BPRS}

Pasal 1 ayat (1) UUPT menentukan bahwa Perseroan Terbatas didirikan oleh 2(dua) orang atau lebih dengan Akta Pendirian yang dibuat dimuka notaris dalam bahasa Indonesia. Namun demikian, secara khusus Pasal 9 ayat (2) UUPS menentukan bahwa BPRS dapat didirikan dan/atau dimiliki oleh:

(1) Warga negara Indonesia dan/atau badan hukum Indonesia yang seluruh pemiliknya warga negara Indonesia;

(2) Pemerintah Daerah;

(3) Dua pihak atau lebih sebagaimana dimaksud pada angka (1) dan (2)

Berdasarkan ketentuan di atas, ketentuan kepemilikan Perseroan Terbatas dalam UUPT dapat dikesampingkan dengan ketentuan Pasal 9 ayat (2) UUPS. Untuk itu, dapat ditentukan bahwa Pemerintah Daerah termasuk dapat memiliki BPRS dengan modal seluruh atau sebagian besar milik Pemerintah Daerah. Namun demikian, sebagai badan hukum, BPRS adalah badan hukum yang berdiri sendiri dengan harta kekayaan sendiri. Untuk itu, Pemerintah Daerah dalam kepemilikannya pada BPRS harus memisahkan sejumlah kekayaan daerah secara terpisah ke dalam BPRS melalui Peraturan Daerah (Perda) yang khusus menentukan jumlah penyertaan modal daerah ke dalam pendirian BPRS.

\section{b. Jumlah Modal BPRS}

Setiap Perseroan Terbatas berdiri dengan modal dasar yang terdiri atas seluruh nilai nominal saham (Pasal 31 ayat (1) UUPT). Paling sedikit 25\% dari modal dasar harus sudah ditempatkan atau disetor penuh dan dibuktikan dengan bukti penyetoran yanga sah (Pasal 33 UUPT). Yang dimaksud dengan bukti setoran yang sah antara lain adalah bukti setoran pemegang saham ke dalam rekening bank atas nama PT tersebut.

Secara khusus UUPS tidak menentukan jumlah minimum modal dasar atau modal disetor yang harus dimiliki oleh BPRS. Pasal 11 UUPS hanya menentukan bahwa besarnya modal disetor untuk mendirikan bank syariah ditetapkan oleh Bank Indonesia. Sebagai UU baru, maka UUPS belum memiliki peraturan perlaksanaan. Untuk itu, sepanjang belum diatur secara khusus maka ketentuan yang lama tetap berlaku. Peraturan Bank Indonesia (PBI) tentang Pedoman Perizinan BPRS menentukan bahwa jumlah minimum modal disetor bagi BPRS yang didirikan di luar ibukota propinsi adalah 500 juta. Dengan demikian jumlah minimum modal dasar berdasarkan ketentuan Pasal 33 UUPT berjumlah 2 milyar rupiah. Pasal 34 UUPT menentukan bahwa penyetoran atas modal saham dapat dilakukan dalam bentuk uang dan/atau dalam bentuk lainnya. Pada umumnya penyetoran saham adalah dalam bentuk uang.

Berdasarkan ketentuan UUPT tidak ditutup kemungkinan penyetoran dalam bentuk lain berupa benda berwujud maupun tidak berwujud yang dapat dinilai dengan uang. Namun, penyetoran saham dalam bentuk lain harus disertai 
rincian yang menerangkan nilai atau harga, jenis atau macam, status, tempat kedudukan dan lain-lain yang dianggap perlu demi kejelasan mengenai penyetoran tersebut. Untuk itu, Pemerintah Daerah dalam menerbitkan Perda tentang penyertaaan modal dalam pendirian BPRS baru harus merinci jumlah modal saham dan modal lain selain saham dengan rincian yang jelas mengenai nilai atau harga, jenis atau macam, status, dan tempat kedudukannya. Perincian tersebut harus dapat mencerminkan jumlah modal yang disertakan dan dipisahkan oleh daerah sebagai harta kekayaan PBRS dalam pendirian BPRS milik daerah tersebut.

c. Memiliki Akta Pendirian yang memuat Angaraan Dasar

Pasal 8 UUPT menentukan bahwa Akta Pendirian memuat anggaran dasar dan keterangan lain berkaitan dengan pendirian PT. Dalam pembuatan Akta Pendirian, pendiri dapat diwakili oleh orang lain berdasarkan surat kuasa. Keterangan lain yang dimuat dalam Akta Pendirian sekurang-kurangnya yaitu:

(1) nama lengkap, tempat dan tanggal lahir, pekerjaan, tempat tinggal, dan kewarganegaraan pendiri perseroan;

(2) nama lengkap, tempat dan tanggal lahir, pekerjaan, tempat tinggal, kewarganegaraan anggota Direksi dan Dewan Komisaris yang pertama kali diangkat;

(3) nama pemegang saham yang telah mengambil bagian saham, rincian jumlah saham, dan nilai nominal saham yang telah ditempatkan dan disetor.
Pasal 15 UUPT menentukan bahwa anggaran dasar memuat sekurang-kurangnya:

(1) nama dan tempat kedudukan perseroan;

(2) maksud dan tujuan serta kegiatan usaha perseroan;

(3) besarnya jumlah modal dasar, dan modal disetor;

(4) jumlah saham, klasifikasi saham, hak-hak yang melekat pada setiap saham, dan nilai nominal setiap saham;

(5) nama jabatan dan jumlah anggota direksi dan dewan pengawas;

(6) penetapan tempat dan tata cara penyelenggaraan RUPS;

(7) tata cara pengangkatan, penggantian, pemberhentian anggota direksi dan dewan komisaris;

(8) tata cara penggunaan laba dan pembagian deviden.

Berdasarkan Pasal 8 UUPS ditentukan bahwa di dalam anggaran dasar bank syariah selain memenuhi ketentuan UUPT memuat pula ketentuan:

(1) pengangkatan anggota direksi dan komisaris harus mendapat persetujuan Bank Indonesia;

(2) Rapat Umum Pemegang Saham (RUPS) bank syariah harus menetapkan tugas manajemen, remunerasi direksi dan komisaris, laporan pertanggungjawaban tahunan, penunjukkan dan biaya jasa akuntan publik, penggunaan laba, dan hal-hal lainnya yang ditetapkan dalam Peraturan Bank Indonesia.

d. Memiliki Direksi dan Dewan Komisaris dengan persetujuan Bank Indonesia 
Secara umum UUPT memberikan pengaturan tentang direksi dan dewan komisaris beserta tugas dan kewenangannya dalam Pasal 92-121 UUPT. Direksi bertugas menjalankan pengurusan perseroan sesuai dengan maksud dan tujuan perseroan. Sedangkan dewan komisaris melakukan pengawasan atas kebijakan pengursan perseroan dan memberikan nasehat kepada direksi. Anggota direksi dan dewan komisaris diangkat Rapat RUPS. Untuk pertama kali, direksi dan dewan pengawas diangkat oleh pendiri dalam akta pendirian.

Secara khusus, UUPS menentukan bahwa syarat, jumlah tugas, kewenangan, tanggung jawab serta hal lain yang menyangkut direksi dan dewan pengawas bank syariah diatur dalam anggaran dasar dan sesuai dengan UUPT (Pasal 28 UUPS). Calon dewan komisaris dan calon direksi wajib lulus uji kemampuan dan kepatutan yang dilakukan oleh Bank Indonesia. Untuk pertama kali, calon dewan komisaris dan calon direksi bank syariah dimuat dalam permohonan persetujuan izin prinsip yang diajukan kepada Gubernur Bank Indonesia.

e. Wajib memiliki Dewan Pengawas Syariah

Pasal 109 UUPT menentukan bahwa PT yang menjalankan kegiatan usaha dengan prinsip syariah wajib mempunyai Dewan Pengawas Syariah (DPS). Selanjutnya secara khusus, UUPS menegaskan kembali dalam Pasal 32 UUPS bahwa DPS wajib dibentuk di bank syariah. DPS diangkat oleh RUPS atas rekomendasi Majelis Ulama Indonesia. DPS bertugas memberikan nasihat dan saran kepada direksi serta mengawasi kegiatan bank agar sesuai dengan prinsip syariah. Ketentuan lebih lanjut mengenai pembentukan DPS diatur dengan Peraturan Bank Indonesia (PBI). PBI baru sebagai peraturan pelaksaan UUPS belum diterbitkan.

Untuk itu, berdasarkan PBI tentang Pendirian BPRS Tahun 2004 ditetapkan ketentuan khusus pembentukan DPS pada bank syariah, sebagai berikut:

(1) sekurang-kurangnya 1 orang dan sebanyak-banyaknya 3 orang

(2) hanya dapat merangkap jabatan sebagai anggota DPS sebanyakbanyaknya pada 2 lembaga perbankan dan 2 lembaga keuangan syariah bukan bank;

(3) satu anggota dapat merangkap jabatan sebagai anggota Dewan Syariah Nasional (DSN).

\subsection{Prosedur Pendirian BPRS}

Berdasarkan bentuk hukum BPRS, maka BPRS adalah badan hukum perseroan terbatas yang mendirikan dengan mengacu pada UUPT yang secara umum mengatur bentuk hukum PT dan UUPS yang secara khusus mengatur hal-hal lain yang terkait dengan bank syariah.

Syarat pendirian di atas dipenuhi menjadi satu kesatuan bagian dari prosedur pendirian BPRS. Berikut ini diuraikan prosedur pendirian BPRS berdasarkan ketentuan UUPT dan UUPS, yaitu:
a. Penerbitan Peraturan Daerah tentang Penyertaaan Modal Daerah bagi Pendirian BPRS milik Daerah 
BPRS adalah badan hukum yang berbentuk Perseroan Terbatas. Untuk itu, setiap BPRS harus memiliki kekayaan sendiri yang terpisah. Pemerintah Daerah sebagai calon pemilik atau calon pemegang saham pada BPRS harus melakukan pemisahan kekayaan daerah melalui Peraturan Daerah yang harus disetujui oleh DPRD. Kekayaan daerah yang dipisahkan harus dimuat secara jelas dan rinci bentuk, jumlah, nilai atau harga dan status serta tempat kedudukannya. Kekayaan daerah yang dipisahkan melalui Perda tersebut selanjutnya dimuat dalam rancangan Anggaran Dasar atau rancangan Akta Pendirian yang akan diajukan sebagai syarat dalam permohonan persetujuan prinsip pendirian BPRS kepada Bank Indonesia.

b. Persetujuan Prinsip Pendirian BPRS oleh Bank Indonesia

Persetujuan prinsip adalah
persetujuan untuk melakukan
persiapan pendirian BPRS yang
diberikan Bank Indonesia bagi
pendirian BPRS baru sebelum Bank
Indonesia mengeluarkan izin usaha
pendirian BPRS. UUPS tidak
mencantumkan dalam ketentuan
pasalnya yang terkait dengan
persetujuan prinsip. Untuk itu,
sepanjang UUPS dan PBI sebagai
peraturan pelaksanaannya yang baru
dari UUPS belum mengatur maka
PBI yang ada tetap diberlakukan.
PBI tentang Pedoman Pendirian
BPRS menentukan bahwa
permohonan persetujuan prinsip
pendirian BPRS diajukan sekurang-
kurangnya oleh salah satu calon
pemilik kepada Dewan Gubernur
Bank Indonesia. Pemilik atau pihak

yang mengajukan permohonan pendirian BPRS wajib melakukan presentasi kepada Bank Indonesia mengenai keseluruhan rencana pendirian BPRS.

Permohonan persetujuan prinsip pendirian BPRS wajib dilampiri dengan dokumen antara lain sebagai berikut:

(1) Rancangan Akta Pendiran BPRS termasuk rancangan anggaran dasar yang sekurang-kurangnya memuat: nama dan tempat kedudukan, kegiatan usaha BPRS, permodalan, kepemilikan, wewenang dan tanggung jawab direksi, dewan komisaris dan Dewan Pengawas Syariah;

(2) Data kepemilikan berupa daftar calon pemilik atau daftar calon pemegang saham berikut rincian besarnya masing-masing kepemilikan saham, dan surat pernyataan dari calon pemegang saham bahwa data atau informasi telah disampaikan dengan benar, beserta laporan keuangan posisi akhir bulan sebelum tanggal pengajuan permohonan atau APBD tahun berjalan yang telah disahkan DPRD untuk BPRS milik Pemda, serta dokumendokumen lain yang telah ditetapkan dalam PBI tentang Pendirian BPRS;

(3) Daftar calon anggota direksi, dewan komisaris, dan Dewan Pengawas Syariah disertai dokumen identitas dirinya dan surat pernyataan tidak melakukan perbuatan tercela dan atau tidak pernah dihukum karena terbukti melakukan tindak pidana, disertai pula surat pernyataan pengalaman kerja dari instansi terkait; 
(4) Rencana susunan dan struktur organisasi serta personalia;

(5) Rencana kerja untuk 3(tiga) tahun pertama yang sekurangkurangnya memuat rencana kegiatan usaha dan langkahlangkahnya, rencana kebutuhan pegawai, dan proyeksi arus kas bulanan selama 36 bulan dimulai sejak BPRS melakukan kegiatan operasionalnya serta proyeksi neraca perhitungan laba rugi;

(6) Studi kelayalam pendirian BPRS antara lain memuat hasil penelaahan mengenai peluang pasar dan potensi ekonomi di wilayah kabupaten/kota tempat kedudukan BPRS dan wilayah operasionalnya;

(7) Surat pernyataan dari pemilik atau pemegang saham bahwa setoran modal tidak berasal dari pinjaman atau fasilitas pembiyaan dalam bentuk apapun dari bank atau pihak lain, tidak berasal dari sumber yang diharamkan menurut prinsip syariah, dan tidak bersal dari dan untuk pencucian uang (money laundering)

Dalam rangka pemberian persetujuan prinsip Bank Indonesia melakukan:

(1) penelitian atas kelengkapan dan kebenaran dokumen;

(2) analisis yang mencakup antara lain tingkat persaingan sehat dan tingkat kejenuhan antar bank yang melaksanakan prinsip syariah dan BPRS;

(3) wawancara terhadap calon pemilik, calon anggota dewan komisaris, calon anggota direksi dan calon Dewan Pengawas Syariah.

Persetujuan atau penolakan atas permohonan persetujuan prinsip diberikan selambat-lambatnya 60 (enam puluh) hari terhitung sejak tanggal permohonan tersebut. Persetujuan prinsip tersebut diberikan untuk jangka waktu 360 (tiga ratus enam puluh) hari sejak tanggal dikeluarkan persetujuan prinsip tersebut dan tidak dapat diperpanjang.

c. Pembuatan dan Penandatanganan Akta Pendirian yang berisi Anggaran Dasar di muka Notaris

Sebagai suatu bentuk hukum PT, maka setiap pendirian BPRS harus didirikan dengan akta pendirian yang dibuat dimuka notaris yang ditandanganani oleh pemilik atau kuasanya. Akta pendirian memuat anggaran dasar yang telah disusun dan disetujui oleh Bank Indonesia melalui pemberian persetujuan prinsip terhadap pendirian BPRS. Anggaran dasar adalah pedoman kerja bagi BPRS dalam menjalankan kegiatan usahanya yang disusun dengan mengacu pada UUPT dan UUPS beserta peraturan pelaksanaannya.

\section{d. Pemberian Izin Usaha BPRS oleh Bank Indonesia}

Pasal 5 UUPS menegaskan bahwa setiap pihak yang akan melakukan kegiatan usaha bank syariah wajib terlebih dahulu memperoleh izin usaha dari Bank Indonesia. Untuk memperoleh izin usaha, bank syariah harus memenuhi persyaratan sekurang-kurangnya tentang: susunan organisasi dan kepengurusan, permodalan, kepemilikan, keahlian di bidang perbankan syariah, dan kelayakan usaha. Persyaratan lainnya ditentukan PBI. 
PBI tentang Pedoman Perizinan BPRS 2004 menentukan syarat lain berupa dokumen pendukung yang harus dilampirkan dalam permohonan izin usaha BPRS kepada Bank Indonesia. Pada prinsipnya, dokumen yang harus dilampirkan adalah sama dengan dokumen permohonan persetujuan prinsip disertai perubahannya jika terjadi perubahan data dari dokumen tersebut. Selain itu, dilampiri pula dengan bukti kesiapan operasional BPRS dan dokumen lain yang dimuat secara lengkap dalam PBI tentang Pedoman Perizinan BPRS 2004.

\section{e. Pengesahan Badan Hukum BPRS oleh Menteri Hukum dan HAM \\ Berdasarkan UUPS, BPRS} adalah Perseroan Terbatas. Sebagai Perseroan Terbatas, BPRS adalah badan hukum. Menurut teori ilmu hukum (doelvermogen theorie), badan hukum adalah pendukung hak dan kewajiban sama dengan manusia pribadi. Untuk itu, harus memiliki kekayaan sendiri yang terpisah dari kekayaan pengurus atau pendirinya (Abdulkadir Muhammad, 2006: 102).

Segala kewajiban hukumnya harus dipenuhi dari kekayaan badan hukum. Kekayaan terpisah ini harus ditentukan secara tegas dalam Anggaran Dasar. Bagi BPRS milik Pemerintah Daerah, untuk setiap pemisahan kekayaan daerah menjadi kekayaan badan hukum harus ditentukan melalui Peraturan Daerah yang secara khusus memisahkan kekayaan daerah untuk pendirian BPRS. Kekayaan badan hukum yang termuat dalam Anggaran Dasar BPRS milik daerah ditentukan berdasarkan Perda tersebut.
UU Perbankan Syariah tidak menentukan secara khusus tentang pengesahan Anggaran Dasar bank syariah oleh Menteri Hukum dan HAM (Menteri) yang menentukan status badan hukum BPRS. Untuk itu, berlakulah ketentuan umum dalam UUPT.

Pasal 9 UUPT menentukan bahwa untuk memperoleh keputusan Menteri mengenai pengesahan badan hukum PT, maka pendiri bersamasama mengajukan permohonan melalui jasa teknologi informasi system adminstrasi badan hukum (Sisminbakum) secara elektronik kepada Menteri dengan mengisi format isian. Namun sebelumnya harus didahului dengan pengajuan nama PT. Format isian memuat sekurang-kurangnya:

(1) nama dan tempat kedudukan PT;

(2) jangka waktu berdirinya PT;

(3) maksud dan tujuan serta kegiatan usaha PT;

(4) jumlah modal dasar, modal ditempatkan dan modal disetor;

(5) alamat lengkap PT.

Dalam hal pendiri tidak mengajukan sendiri permohonan tersebut, maka pendiri hanya dapat memberi kuasa kepada notaris.

Permohonan untuk memperoleh pengesahan tersebut harus diajukan paling lambat 60 (enam puluh) hari terhitung sejak tanggal Akta Pendirian ditandatangani dengan dilengkapi dokumen pendukung yang telah ditentukan dalam Peraturan Menteri.

Terhadap format isian yang memenuhi syarat, Menteri langsung menyatakan tidak berkeberatan atas permohonan tersebut secara elektronik. Sebaliknya jika keberatan maka diberitahukan pula kepada 
pemohon tentang penolakan tersebut beserta alasannya secara elektronik. Dalam jangka watu 30(tiga puluh) hari sejak tanggal pernyataan tidak berkeberatan, pemohon wajib menyampaikan secara fisik surat permohonan disertai dokumen pendukungnya. Dalam jangka waktu paling lambat 14(empat belas) hari sejak permohonan itu dipenuhi secara lengkap, Menteri menerbitkan keputusan tentang pengesahan badan hukum PT (BPRS) tersebut yang ditandatangani secara elektronik (Pasal 10 UUPT).

\section{f. Pendaftaran dan Pengumuman}

UUPS tidak memberikan pengaturan tentang pendaftaran dan pengumuman bagi bank syariah termasuk BPRS. Pengaturan mengenai pendaftaran dan pengumuman ditemukan dalam UUPT. Untuk itu, sebagai PT maka BPRS harus pula melakukan pendaftaran dan pengumuman.

Pasal 29 UUPT menentukan bahwa setiap PT atau perseroan wajib didaftarkan. Pendaftaran tersebut diselenggarakan oleh Menteri Hukum dan HAM. Daftar perseroan memuat seluruh informasi lengkap dari perseroan tersebut yang termuka untuk diketahui umum. Data perseroan yang dimuat dalam daftar perseroan dimasukkan bersamaan pada tanggal Keputusan Menteri mengenai pengesahan badan hukum perseroan tersebut.

Setelah pendaftaran selesai dilakukan, maka selanjutnya Menteri wajib mengumumkan berdirinya PT baru dalam Tambahan Berita Negara RI. Pengumuman tersebut berisi Akta Pendirian dan Surat Keputusan Menteri mengenai pengesahan badan hukum. Pengumuman tersebut dilakukan oleh Menteri dalam waktu paling lambat 14(empat belas) hari terhitung sejak tanggal diterbitkannya Keputusan Menteri mengenai pengesahan badan hukum (Pasal 30 UUPT).

\subsection{Kepemilikan Modal Daerah melalui Penyertaan Modal}

Berdasarkan kajian pendirian BPRS baru di atas terlihat bahwa pendirian BPRS baru membutuhkan berbagai kajian mendalam, pemenuhan syarat yang cukup banyak, harus didukung oleh berbagai dokumen pendukung dan harus mengikuti prosedur pendirian yang cukup memakan waktu. Untuk itu, sebagai kajian pembanding akan diuraikan singkat alternatif lain bagi daerah dalam rangka pengelolaan aset dari dalam keikutsertaan bagi pembangunan ekonomi masyarakat daerah tersebut. Hal ini dapat pula dilakukan oleh pemerintah daerah dalam rangka peran aktif bagi pemberdayaan kegiatan ekonomi secara berdaya guna dan berhasil guna bagi masyarakat dan bagi peningkatan pendapatan asli daerah.

Keikutsertaan Pemerintah Daerah dengan pembelian atau pengambilalihan saham pada BPRS yang telah berdiri merupakan alternatif tercepat dibandingkan dengan pendirian BPRS baru. Berdasarkan kajian hukum ekonomi, pembelian atau pengambilalihan saham dilakukan dengan syarat dan prosedur yang relatif sederhana atau singkat sehingga tidak membutuhkan waktu lama. Pemerintah Daerah dapat melakukan pembelian atau pengambilalihan modal atau saham BPRS tersebut berdasarkan kajian mendalam dan dengan alasan yang 
menguntungkan dalam peningkatan peran Pemda bagi kehidupan ekonomi masyarakat daerahnya dan peningkatan aset Pemda.

\section{Simpulan}

1. Bahwa BPRS didirikan dengan memenuhi syarat dan berdasarkan prosedur tertentu sebagaimana ditentukan dalam UU Perbankan Syariah dan UU Perseroan Terbatas. Syarat pendirian BPRS meliputi syarat bentuk hukum berupa Perseroan Terbatas dan jumlah modal dasar minimal 2 milyar rupiah serta memiliki anggaran dasar. Prosedur pendirian BPRS dilakukan dengan cara yaitu: a. penerbitan Peraturan Daerah tentang Penyertaaan Modal Daerah bagi Pendirian BPRS milik Daerah, b. persetujuan prinsip pendirian BPRS oleh Bank Indonesia, c. Pembuatan dan penandatanganan Akta Pendirian yg berisi Anggaran Dasar di muka notaris, d. Pemberian izin usaha BPRS oleh Bank Indonesia, e.pengesahan badan hukum BPRS oleh Menteri Hukum dan HAM, f. pendaftaran dan pengumuman yang diselenggarakan oleh Kementrian Hukum dan HAM bersamaan dengan pengesahan Badan Hukum.

2. Bahwa keikutsertaan Pemerintah Daerah dengan pembelian atau pengambilalihan saham pada BPRS yang telah berdiri merupakan alternatif tercepat dibandingkan dengan pendirian BPRS baru. Berdasarkan kajian hukum ekonomi, pembelian atau pengambilalihan saham dilakukan dengan syarat dan prosedur yang relatif sederhana atau singkat sehingga tidak membutuhkan waktu lama. Pemerintah Daerah dapat melakukan pembelian atau pengambilalihan modal atau saham BPRS tersebut berdasarkan kajian mendalam dan dengan alasan yang menguntungkan dalam peningkatan peran Pemda bagi kehidupan ekonomi masyarakat daerahnya dan peningkatan aset Pemda.

\section{Daftar Pustaka}

Djazuli, H.A. dan Yadi Janwari. 2002. Lembaga-Lembaga Perekonomian Umat (Sebuah Pengenalan). Penerbit Raja Grafindo Persada, Jakarta.

Dewi, Gemala. 2006. Aspek-Aspek Hukum Dalam Perbankan dan Perasuransian Syari'ah di Indonesia. Edisi Revisi. Penerbit Kencana Prenada Media Group, Jakarta.

Sholahuddin, M, 2006. Lembaga Ekonomi dan KeuanganI Islam. Penerbit Muhammadiyah University Press. Surakarta.

Muhammad. 2005. Manajemen Pembiayaan Bank Syari'ah. Penerbit Akademi Manajemen Perusahaan YKPN, Yogyakarta.

Djamil, Fathurrahman. 2001. Hukum Perjanjian Syari'ah, Dalam Kompilasi Hukum Perikatan. Penerbit Citra Aditya Bakti, Bandung. Antonio, Muhammad Syafi'i. 1999. Bank Syari'ah Bagi Bankir \& Praktisi Keuangan, 
Penerbit Tazkia Institute, Jakarta.

Antonio, Muhammad Syafi'i. 2000. Bank Syari'ah Suatu

Pengantar Umum. Edisi

Khusus. Penerbit Tazkia Institute, Jakarta.

Sjahdeini, Sutan Remy. 1999.

Perbankan Islam dan

Kedudukannya Dalam Tata

Hukum Perbankan Indonesia.

Penerbit Pustaka Utama

Grafiti, Jakarta.

Sudarsono, Heri. 2004. Bank dan

Lembaga Keuangan Syari'ah.
Penerbit Universitas Islam Indonesia Press, Yogyakarta.

Ali, Muhammad Daud. 1983. AsasAsas HukumI Islam. Penerbit Bulan Bintang, Jakarta.

Ash-Shiddieqie, T.M. Hasbi. 1984. Pengantar Fiqih Muamalah. Penerbit Bulan Bintang, Jakarta. 